\title{
Programa de pesquisa neonatal de hipotiroidismo congénito de la provincia de Buenos Aires: 1.377.455 niños evaluados en diez años de experiencia
}

\author{
VERÓNICA G. GONZÁLEZ1 ${ }^{1}$ ZULMA C. SANTUCCI ${ }^{1}$, JORGELINA PATTIN $^{1 *}$, \\ MARÍA APEZTEGUÍA ${ }^{2 * *}$, GUSTAVO BORRAJO ${ }^{3 *}$ \\ 1. Hospital de Niños "Sor María Ludovica". La Plata. \\ 2. Comisión de Investigaciones Científicas de la provincia de Buenos Aires. \\ 3. Laboratorio de Detección de Errores Congénitos. Fundación Bioquímica Argentina. \\ * Bioq. \\ ** Lic.
}

\begin{abstract}
Newborn screening for congenital hypothyroidism in the province of Buenos Aires. Ten years experience in 1.377 .455 evaluated children

Introduction. Neonatal screening program for congenital hypothyroidism in the province of Buenos Aires began in 1995. Its aim was the early detection and treatment of infants with this disease. The objective of this paper was to analyse its performance during the 2000-2004 year period and compare it to the previous 1995-1999 year period. Population: Every newborn in the province of Buenos Aires to whom the screening test for congenital hypothyroidism was performed in the reference centre, since April 1995 to December 2004. Results: 1.377 .455 newborns were evaluated with coverage of $56.8 \%$ in the province of Buenos Aires. 568 newborns with congenital hypothyroidism were confirmed. The incidence of the disease was $1: 2,425$ and the screening positive predictive value was $88.1 \%$. During the second period, the total coverage and the coverage of newborns from hospitals dependent of province's ministry $(98 \%)$ were similar to those from the previous period. Median age of sample collection and at start of treatment were 6 and 19 days for private hospitals, 3 and 16 days for municipal hospitals, and 2 and 17 days for hospitals dependent of province' ministry, respectively. Conclusions: Screening program for congenital hypothyroidism has successfully contributed to prevent mental retardation of this etiology in the province of Buenos Aires, making possible the early detection of the disease. Nevertheless, private and municipal coverage should be extended and the age at start of treatment should decrease to less than 15 days in every child with congenital hypothyroidism.
\end{abstract}

(Key words: Neonatal screening, congenital hypothyroidism, mental retardation).

Arch Argent Pediatr 2007; 105 (5): 390-397/390

Correspondencia a:

Verónica G. González

E-mail: vebibi@yahoo.com.ar

Conflicto de intereses: nada que declarar. 


\section{RESUMEN}

Introducción: En 1995 se implementó en la provincia de Buenos Aires el programa de pesquisa de hipotiroidismo congénito para su diagnóstico y tratamiento precoz. El objetivo de este trabajo fue analizar los registros durante el período 2000-2004 y compararlos con los del período previo (1995- 1999). Población: Todos los recién nacidos en el ámbito de la provincia de Buenos Aires en quienes se efectuó la prueba de pesquisa de hipotiroidismo congénito en el centro de referencia, entre abril de 1995 y diciembre de 2004. Resultados: Se evaluaron 1.377.455 recién nacidos, que representaron una cobertura del $56,8 \%$ de todos los nacidos vivos de la provincia. Se confirmaron 568 casos de hipotiroidismo congénito, con una incidencia de 1:2.425 y un valor predictivo positivo de pesquisa del $88,1 \%$. En el segundo período, la cobertura global del programa se mantuvo similar a la del período anterior, al igual que la de los hospitales dependientes del Ministerio de Salud de la provincia (98\%). Las edades (medianas) para la obtención de la muestra e inicio del tratamiento fueron, en el sector privado, de 6 y 19 días, en el municipal, 3 y 16 días, y en el provincial, 2 y 17 días, respectivamente. Conclusiones: Con la detección temprana de los casos de hipotiroidismo congénito, el programa ha contribuido significativamente a la prevención del retardo mental de ese origen en la provincia de Buenos Aires. Deberá extenderse la cobertura en los ámbitos municipal y privado y disminuir la edad de inicio del tratamiento a menos de 15 días de vida.

(Palabras clave: Pesquisa neonatal, hipotiroidismo congénito, retardo mental).

Arch Argent Pediatr 2007; 105 (5): 390-397/390

ESTE TRABAJO LO PUEDE ENCONTRAR EN EXTENSO EN WWW.SCIELO.CL 